\title{
ming Hal: $21-36$ \\ DETERMINANTS OF SUSTAINABLE COMPETITIVE ADVANTAGE DUE TO AN IT-ENABLED STRATEGY
}

\author{
Yuni Nustini \\ Economics Faculty of Universitas Islam Indonesia
}

\begin{abstract}
Abstrak
Teknologi informasi (TI) telah dinyatakan sebagai sumber kelangsungan daya saing yang dapat meningkatkan kinerja dan posisi bersaing perusahaan. Namun, tersebar luas kepercayaan diantara komunitas manajemen perusahaan bahwa setiap kinerja perusahaan yang dihasilkan oleh teknologi informasi berumur pendek, karena kinerja tersebut mudah ditiru. Tujuan dari penelitian ini adalah untuk menentukan faktor-faktor strategi teknologi informasi yang dapat menghasilkan keunggulan daya saing perusahaan yang berkelanjutan.

Penelitian ini menggunakan sampel dari 2 kelompok data. Kelompok pertama yaitu sampel perusahaan yang menggunakan strategi infomasi teknologi dalam mempertahankan keunggulan daya saing perusahaan, data dihimpun dari survei yang diadakan oleh majalah Warta Ekonomi terhadap praktek e-bisnis terbaik tahun 2002. Kelompok kedua yaitu sampel perusahaan yeng tidak menggunakan strategi teknologi informasi dalam mempertahankan keunggulan daya saing perusahaan, data dihimpun dari survei yang diadakan oleh majalah Investor terhadap kinerja perusahaan terbaik tahun 2002. Pengujian hipotesis menggunakan t-statistik untuk menguji mean dalam konsep matching dan regresi sensor untuk menguji probabilitas masing-masing variabel di dalam distribusi.

Hasil dari penelitian ini menunjukan bahwa kemampuan manajemen perusahaan dalam memahami, mengembangkan dan mengolah informasi teknologi adalah berhubungan secara signifikan terhadap durasi dari keunggulan daya saing. Hal ini berarti perusahaan-perusahaan yang memiliki kemampuan manajemen perusahaan yang tinggi dalam memahami, mengembangkan, dan mengolah teknologi informasi akan memiliki keunggulan daya saing yang berkelanjutan lebih lama. Sebaliknya, kemampuan informasi teknologi secara teknis dan infrastruktur teknologi informasi adalah insignifikan secara statistic terhadap durasi dari keunggulan daya saing.
\end{abstract}

Kata kunci: teknologi informasi, strategi TI, kelangsungan, keunggulan daya saing

\section{INTRODUCTION}

Recent studies have established that the successful use of information technology (IT) can improve a company's performance and competitive position (Bharajwaj, 2000; Stratopoulos and Dehning, 2000). However, there is widely held belief among the management community that any performance advantage granted by IT is short lived because computer-based information system (IS) are easily replicated (Alter, 1998; Ballou and Slater, 1994). Competitors will attempt to neutralize the competitive advantage of the successful users by copying and possibly improving the IT used (Kettinger et al., 1994; Mata et al., 1995). Therefore, companies today tend to concern about the information technology strategy that can run for long-term period.

In 1970s and 1980s, there were number of companies that enabled them to enjoy competitive advantage for several years before competitors imitated them. For 
example, Federal Express (FedEx) package tracking system that was copied by UPS, DHL, and others after three to five years (Turban, Mclean, Wetherbe, 2002). Due to advance in system development as companies become larger and more sophisticated, they develop sufficient resources that quickly duplicate the successful system of their competitors, sometimes in months rather than years. For example Alamo Rent-a-Car now offers a frequent renter (Quick Silver) card similar to the one offered by National Car Rental (Turban, Mclean, Wetherbe, 2002). The facts above are the extreme examples of major problem that companies now face in sustaining their competitive advantage.

This research will broadly examine factors that are believed to lead a sustainable competitive advantage due to an IT-enabled strategy and examine what the companies do for competitive strategy to sustain its competitive advantage by using IT-application and analyze specific factors that can lengthen the period of its competitive advantage or shorten the period.

Dehning and Stratopoulos have conducted the same research in 2003 with the research field in the United Stated. Meanwhile in this research, the field of study is in Indonesia so the data and the variables used are adjusted to the available sources. Hopefully, this research will find out different results because it is done in the different country with different sources of data.

This research will be processed in four steps. The first step is to identify companies that have a competitive advantage due to an IT-enabled strategy and companies who do not as competitors. The second step is to measure a company's competitive advantage through ROA differential between E-companies and matched companies. Return on assets (ROA) is the measure of competitive advantage. The third is to analyze the duration of competitive advantage by doing censored regression on the six variables (managerial IT skills, technical IT skills, IT infrastructure, CEO rating, differential growth rate, and ROA differential). The last step is to determine the factors that affect to the sustainable competitive advantages.

In order to make it clearer, the study will be focused on the determination on factors that can lead a sustainable competitive advantage due to an IT-enabled strategy.

\section{THEORY AND HYPOTHESIS DEVELOPMENT}

\section{The Competitive Advantages Cycle}

Businesses are endowed with a mixed bag of resources. The superior assets and capabilities are the source of positional advantages. In dynamic cycle, strategy has two purposes each to put impediments in the way of competitors to protect current advantages and to sustain, to renew advantages in dynamic environments; managers need to understand how advantages are created and how they are eroded (Day et al., 1997).

The creation and maintenance of advantages is thus a continuous cycle, as illustrated in figure 1. 
Figure 1: Competitive Advantage Cycle

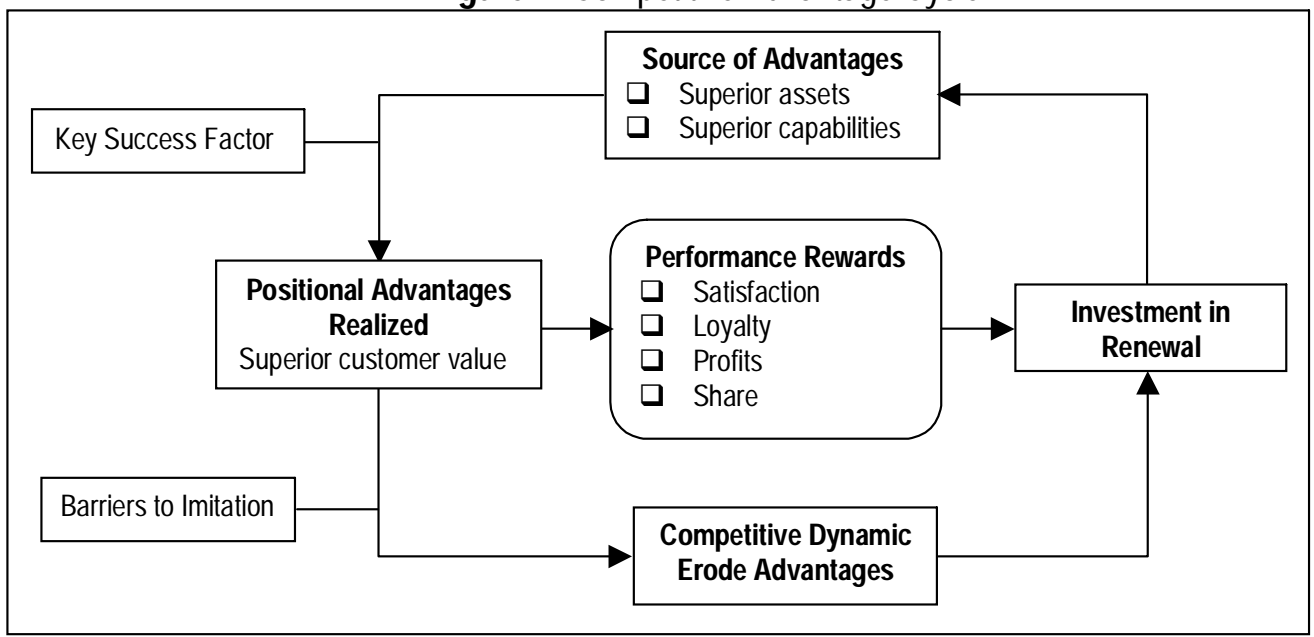

Source: Day, Reibstein, and Gunther, Wharton Dynamic competitive strategy, 1997, page 53, adapted.

\section{Source of Advantages}

Advantages are defined by position or by the assets and capabilities. These advantages contribute to a successful competitive strategy. Superior assets are the tangible resources because endowments the business has accumulated. While distinctive capabilities are the glue that holds these assets together and enables them to be deployed advantageously (Day et al., 1997).

\section{Positional advantages realized}

Positional superiority defines advantages. There are two frameworks of position, low cost or differentiation and value disciplines. A low-cost strategy offers acceptable value to customers to maintain prices close to the average of competitors and the company, while a differentiation strategy is framed in external customer terms, and competitive advantage is achieved by offering superior quality. These two concepts -cost and quality- are brought together in the concept of customer value, which is the sum of perceived benefits received minus perceived cost incurred in acquiring and using the product or service (Day et al., 1997). Today, IT enables firms to compete on both low cost and product differentiation simultaneously. It is used to rapidly link process and work groups in order to produce customized products that are exactly what a customer wants (Pins, Victor and Boyton, 1993). The framework of value disciplines uses a consistent externally oriented schematic for framing the generic strategy (Day et al., 1997). There are three "value disciplines" strategies which differ in the core of proposition; the capabilities, assets, and business system to be mastered; the organizational structure and culture that are needed and a third 
values qualities of relationship, trust, personalized services, and advice when choosing a supplier (Treacy and Wiersema, 1995; Day et al., 1997).

\section{Performance rewards}

The indicators of a successful competitive strategy are market share, profitability, customer satisfaction and loyalty. Market share is best viewed as an outcome of strategic moves, and a measure of success, and not an intrinsically valuable asset to be bought or sold (Day et al., 1997). Profitability is the reward from past advantages after the current outlays needed to sustain or enhance future advantages have been made (Day et al., 1997). These both mechanisms are operating concurrently and it is most accurate to think that both share and profitability as manifestation of superior assets, capabilities and strategic direction. Customer Satisfaction and Loyalty has an important role in the sense of a high level of their commitment or a high percentage of purchases, which can drive to the profitability. As stated by Reicheld and Sasser, companies are able to improve profits anywhere from $25 \%$ to $85 \%$ by reducing customer defections by $5 \%$. Some companies are using customer retention or length of relationship as a proxy for loyalty.

\section{Competitive dynamic erode advantages}

The term "sustainable' advantage implies an unwarranted momentum, persistence, and resistance to imitation. Sustainability is a matter of degree (Day et al., 1997). A sustainable strategic advantage is a strategic advantage that can be maintained for some length of time (Turban et al., 2002)

How a firm can sustain their competitive advantages for long-term period has become common problem to be solved. As stated by Grand and Spring (1991) and Day et al. (1997), five conditions that tend to make an asset or capability a sustainable source of advantages. Those conditions are; Valuable, a condition that makes a significant contribution to superior customer value, Durable and not vulnerable to rapid depreciation or obsolescence because of the pace of technological change, shifts in customer requirements, or the depletion of non-renewable assets, Causal ambiguity, It is deepened when the capability requires a complex pattern of coordination among diverse types of resources. This means that few individuals have a complete grasp of the entire system and the organizational culture adds the complexity. It also has the activities of transaction specific assets that can create a high degree of interdependency, which is hard disentangle and imitate, Barriers to duplication, it means that the competitors find difficulties to duplicate because they cannot amass the same assets and capabilities. Sustainability depends on being able to impede these moves. Direct acquisition of the necessary resources will be impeded or facilitated, depending on; The immobility or scarcity of the resources (Barney, March 1991), the best way to block imitation is to create one of kind resources, and the accuracy of the information about the value of the resource. The established firm will usually have better insights into the productivity of the individual assets, and the 
capabilities are used to utilize these assets. A further barrier to internally developing assets and capabilities comes from time compression diseconomies (Ghemawat, 1991) refers to resources, which are relatively easy or inexpensive to imitate, but the process is time-consuming (Barney, 1991, 1997; Bharadwaj, 2000; Collis and Montgomery, 1995; Feeny and Ives, 1990; Mata et al., 1995; Peteraf, 1993; Wernerfelt, 1984; Stratopoulus and dehning, 2002). For example, a reputation for exceptional quality requires consistency and continuous improvement over a long period. The last condition is credible threats of retaliation, it is the way to create barriers to imitation through threats of retaliation. Early movers may be able to deter imitation by rivals who might be able to overcome the barriers to duplicability with credible threat of retaliation (Day et al., 1997).

\section{Investment in renewal}

As stated by Day, Reibstein, and Gunther (1997), the process of renewal can be achieved by developing new assets, upgrading existing capabilities, acquiring the alternatives resources that are threatening the company's current position, and investing to extend the resources into new competitive arenas.

\section{Using IT for Sustaining the Competitive Advantage}

It is now commonly held belief that the competitive use of IT has the potential to provide easier access to markets; to change product through differentiation; to provide cost efficiencies; and to change the nature of firm industry (Kettinger et al., 1994). The theoretical argument that sustainability is possible can be attributed to certain IT resources and capabilities that are difficult to imitate (Dehning and Stratopoulos, 2003). When an IT-enabled strategy is combined with such resources and capabilities, firms will be able to gain a sustained competitive advantage through barriers to entry, switching costs and mobility barriers (Porter, 1979, 1980; Mata et al., 1995; McFarlan, 1984; Sambamurthy, 2000; Dehning and Stratopoulos, 2003). These may include managerial IT skills, technical IT skills, and IT infrastructure.

Turban, Mclean, and Wetherbe (2002) presented some ways to accomplish competitive sustainability with the help of the IT, which are explained as using inward systems that are not visible to competitors. The Strategic advantage is sustained as long as the systems remain a secret and the competitors do not imitate it, developing a comprehensive, innovative, and expensive system that is very difficult to duplicate, and combining a Strategic Information System (SIS) with structural changes.

These theoretical discussions lead to the hypothesis formulation.

\section{Hypothesis Formulation}

The hypotheses can be formulated as follows:

H1: Companies with superior managerial IT skills will have a longer duration of sustained competitive advantage. 
H2: Companies with superior technical IT skills will have a longer duration of sustained competitive advantage.

H3: Companies with superior IT infrastructure will have a longer duration of sustained competitive advantage.

\section{METHODOLOGY}

Dataset

Empirical testing in this research implies a longitudinal comparison between a set of companies that have competitive advantage due to an IT-enabled strategy and their competitors who do not.

This study is based on two subsets of a database. The first is compiled from a survey of leading practice of e-business conducted by Warta Ekonomi magazine no. 23/THN. XIVI October 9, 2002. A survey designed to collect information concerning management practices related to implementation of IT as well as e-business. The second is compiled from a survey of top performer companies conducted by Investor magazine 55th edition, May 22 - June 4, 2002. A survey concerns to the aggregate financial performances of the companies.

Other additional information will be taken from Jakarta Stock Exchange (JSX) especially for the company's financial statement from the year 1998 to 2003.

Given the intrinsic complexity of the task of identifying companies with an IT-enabled strategy, we consider surrogate lists that can offer a reasonable fit to the description. The Warta ekonomi E-company award 2002, which was participated by 56 firms, seems to be a good fit. We see an alignment between the criteria and the factors that previous literature asserts might lead to a sustainable competitive advantage due to an IT-enabled strategy. The list of companies is limited to those that conduct some e-commerce activities such as IT vendor or ISP (internet service provider). The creation of Warta Ekonomi is based on the following 7 criteria: customer value (the value of customer received from all company's aspects to the products and services), efficiency process (the company's capability to optimal the input ratio over the output), innovation rate (the amount of company's innovation in a year), human resources (company's human resources which can support the strategy of IT implementation), management commitment (the company's management commitment on the IT implementation, revenue per total asset (the company's revenue per total asset for the last three years), and the internet usage (the rate of the internet used to support IT implementation). These criteria serve as surrogate measures for the IT resources and capabilities that may lead to a sustained competitive advantage due to an IT-enabled strategy.

By default, companies that have a competitive advantage but are not selected by Warta Ekonomi use a less IT-enabled strategy. We use the Investor 100 best-listed companies with a competitive advantage that is not due to an IT-enabled strategy. The criteria used to select the top industry performers are a year return (\%), 
a year sales growth (\%), Three years sales growth (\%), Net margin 2001 (\%), return on equity (\%), asset turn over (\%), volatility, liquidity, a year net operating income growth and number of share holders.

\section{Research Variables}

Variables used in this research are independent and dependent variables. The former variable is dependent; it is used to measure six independent variables, which contained of each three explanatory variables and control variables. Control variables are added to the model to eliminate any significant results from correlated omitted variables, and to reduce the unexplained variance in the model, which makes the model more efficient. Those variables are:

Management rate (MNGMTRATE), which is the variable used is to measure the managerial IT skills. It is measured by seeing innovation scale as the representative of the rating of how well management has positioned the IS of the organization to service their business needs. Innovation is measured from the amount of innovation a year and the kind of innovation.

Technical factor (TECHFACTOR) is the proxy of technical IT skills. It is measured by calculating the percentage of the employees who are able to operate the computer system divided by the total amount of employees, the amount of staff training per year, and other human resource criteria at minimum requirements.

Infrastructure factor (INFRAFACTOR) is the proxy of IT infrastructure components. It is measured from the comparisons of personal address with the total of employees, and the availability of on-line services and company's web sites.

CEO rating (CEORATE) as the control variable of research model that is measured from the rating of how well the top management believes the company uses IT or management's commitment in implementing IT which can be seen from the amount of company's IT investment.

Growth differential (GROWDIFF) as the control variable, which is the differential in 5-years growth rate in profits from 1998-2002 annually between Ecompanies and matched control companies.

The Differential of Return on Assets (ROADIFF) as the control variable, which is measured from the differential of ROA 2003 between E-companies and matched control firms. ROA is calculated from income from continuing operation before interest expense and taxes (EBIT) divided by total Assets.

\section{TECHNIQUES OF DATA ANALYSIS}

\section{Measure of Competitive Advantage}

Return on assets (ROA) is used as a measure for competitive advantage. ROA has been used in studies on the relation between investment in IT and productivity (Barua et al., 1995; Hitt and Brynjolfsson, 1996; Weill, 1992; Dehning and Stra- 
topoulos, 2003), as well as in recent studies on the relation between IT and competitive advantage (Bharadwaj, 2000; Dehning and Stratopoulos, 2000, 2003).

A matched-pair design is used to test the research question. A matched control will be used as a benchmark to measure differential performance. Competitive advantage is defined as positive ROA differential between the Warta Ekonomi (WRTE) and a direct competitor. The control group is identified through the matching concept procedure with the minimum Euclidean distance from WTRE company. Both group of companies are matched and compared directly as illustrated in figure 2 .

Figure 2: Illustration of direct sample comparison

\begin{tabular}{|c|c|c|}
\hline $\begin{array}{c}\text { WARTA EKONOMI } \\
\text { (IT firms) }\end{array}$ & Direct & $\begin{array}{c}\text { INVESTOR } \\
\text { (Non-IT firms) }\end{array}$ \\
WRTE 56 companies & Test & \begin{tabular}{c} 
INVR 100 companies \\
\hline
\end{tabular}
\end{tabular}

Each WRTE company is matched with its closest competitors using the following procedure. First, all companies that are not listed in Jakarta Stock Exchange (JSX) removed from the list. Second, the companies are identified based on the similar industry sector. Third, the nearest competitors are selected by simultaneously matching on sales and total assets. The nearest competitors are identified as the companies with the minimum Euclidean distance from the WRTE Company. It is measured using the equation below:

The equation:

$$
D_{i}=\sqrt{ }\left\{\left(S_{\text {INVR }}-S_{\text {WRTE }}\right)^{2+}\left(A_{\text {INVR }}-A_{\text {WRTE }}\right)^{2}\right\}
$$

Where;

$\mathrm{D}_{\mathrm{i}} \quad=$ the Euclidean distance for Investor (INVR) potential match company

$\mathrm{S}_{\mathrm{INVR}}=$ sales for Investor (INVR) potential match company

$A_{\text {INVR }}=$ total assets Investor (INVR) for potential match company

$\mathrm{S}_{\text {WRTE }}=$ sales for Warta Ekonomi (WRTE) company to match

$A_{\text {WRTE }}=$ the total assets for Warta Ekonomi (WRTE) company to match

Finally, the rest companies are removed from the list of potential matches.

After completing the matching procedure, there are 10 companies of INVR regarded as the nearest competitors. Table 2 contains of final samples used in this research. Each group remains 10 companies of IT firm (WRTE) and 10 companies of non-IT firm (INVR) as the control firm.

Table 1 presents summary of statistics for the two groups in terms of total assets and net sales, in which their mean of sales and total assets are approximately equal. In this case, a t-test for difference in means is not significant for total assets ( $p$ $=0.85)$ or net sales $(p=0.62)$. 
Table 1: Comparative statistic (year 2003)

\begin{tabular}{cccccc}
\hline Variable & & N & Mean & Std. Deviation & Std. Error Mean \\
\hline Total Assets $^{a}$ & WRTE & 10 & 6106790 & 7393786,800 & 2338121 \\
& INVR & 10 & 6747248 & 7181369,815 & 2270949 \\
Sales $^{b}$ & WRTE & 10 & 1971763 & 3299747,796 & 1043472 \\
& INVR & 10 & 3000383 & 5431236,902 & 1717508
\end{tabular}

${ }^{*}$ Comparative statistic for the year 2003 quarterly on September (Rupiah amounts in million). Results reported are the mean and the standard deviation of 2003 total assets and 2003 sales for 10 Warta Ekonomi companies (WRTE) and their matched control group companies. $t$ - values are the difference in means between the two groups.

a $t$ - value for difference in means $=-0,20, p=0,85$.

$\mathrm{b} t$ - value for difference in means $=-0,51, p=0,62$.

Table 2: Sample Size of Data

\begin{tabular}{|c|c|c|}
\hline & $\begin{array}{l}\text { Warta ekonomi } \\
\text { WRTE }\end{array}$ & $\begin{array}{c}\text { Investor } \\
\text { INVR }\end{array}$ \\
\hline Initial Population & 56 & 99 \\
\hline \multicolumn{3}{|l|}{ Less: } \\
\hline a. Not Listed In ICMD (JSX) & 23 & - \\
\hline \multicolumn{3}{|l|}{ b. No. of unmatched firms: } \\
\hline - Industry sector & 6 & 71 \\
\hline - Direct competitors & 17 & 18 \\
\hline No. of sample & 10 & 10 \\
\hline
\end{tabular}

\section{Data Analysis}

The dependent variable in this research is the duration of competitive advantage. To calculate the duration of competitive advantage we counted the number of consecutive years the WRTE company has positive ROA differential relative to their direct competitor. It conveys qualitative (company with competitive advantage or competitive disadvantage) as well as quantitative information (duration of advantage). In this calculation, we have three explanatory and control variables as the important factors in contributing the duration of sustained competitive advantage. According to Dehning and stratopoulos (2003) managerial IT skills, technical IT skills and IT infrastructure are the most likely contributors to the sustainability of competitive advantage. Three variables serve as control variable; CEO rating of how well top management believes the company is using IT has no prediction made whether it should be positively or negatively related to the duration. The difference in 5-year growth rate in profits from 1998 to 2002, and the difference in ROA in 2003 between the WRTE company and matched control firm are in the model to control for differences in the duration of competitive advantage that are not due to an IT-enabled strategy. This results in the following model: 


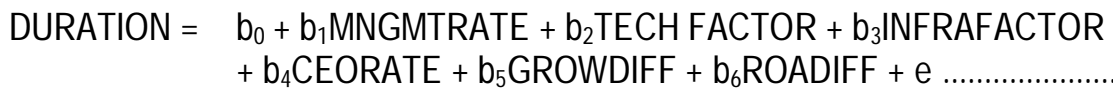

Where; DURATION is the number of consecutive years WRTE firm has positive ROA differential relative to their direct competitor. Duration $=0$, when the control firm has a competitive advantage. MNGMRATE is the rating of how well IS management has positioned the IS to service business needs, on a scale of 1-10. TECH FACTOR is factor representing technical IT skills (human resource), in a scale of 110. INFRA FACTOR is factor representing IT infrastructure (internet), in a scale of 110. CEORATE is management commitment on IT application, in a scale of 1-10. GROWDIFF is differential in 5-year growth rate (annually) in profits from 1998 to 2002 between e-company and matched control firms. And ROADIFF is the differential in ROA in 2003 between the e-company and matched control firms. The scale used is based on the data source (Warta Ekonomi magazine no. 23/THN. XIV/ October 9,2002 ) with scale 1-10.

A company will have competitive advantage when its duration is in the positive number. Meanwhile the company with competitive disadvantage has zero or negative duration.

To have better result, which tends to be less bias, the researcher uses censored regression (Tobit model). This regression makes possible to account for the qualitative difference between limit (zero) observations and non-limit continuous observations. When the data censored, the distribution applied to the sample data is mixture of discrete and continuous distributions. It is more capable in censored regression than conventional regression. Estimating this model with OLS will lead to inconsistent estimate; OLS estimates tend to be biased, even asymptotically (Green, 1997; Kennedy, 1998; Maddala, 1989). For a more detailed discussion of the censored regression model used, see Appendix A.

\section{DISCUSSION OF EMPIRICAL RESULTS}

\section{The Censored Regression (Tobit)}

To analyze the distribution, we defines a new random variable of yi transformed from the original one $\mathrm{yi}^{\star}$, by eq. (1).

$y i=\left\{y^{\star}\right.$ if $\left.\mathrm{yi}^{\star}>0\right\},\left\{0\right.$ if $\left.\mathrm{yi}^{\star}<0\right\} \mathrm{Eq}$.

Where:

$\mathrm{yi}=$ Duration

$\mathrm{yi}^{\star}=$ the number of consecutive years a company sustains its competitive advantage.

This equation presents that yi* is observed for values greater than zero, i.e. when the company enjoys a competitive advantage, and censored for values less or equal to zero, i.e. when the company does not enjoy a competitive advantage. 
Table 3 shows the descriptive statistics of each variable as an explanatory and control variables in the regression, which contains the means and standard deviations.

Table 3: Variable descriptive statistics

\begin{tabular}{lcc}
\hline \multicolumn{1}{c}{ Variable } & Mean & Standard deviation \\
\hline DURATION & 0.800000 & 0.421637 \\
MNGMTRATE & 4.500000 & 4.116363 \\
TECHFACTOR & 4.400000 & 2.756810 \\
INFRAFACTOR & 5.200000 & 2.780887 \\
CEORATE & 4.200000 & 3.084009 \\
GROWDIFF & -52.20000 & 130.3319 \\
ROADIFF & 19.50000 & 88.86225 \\
\hline
\end{tabular}

Table 4: Censored Regression Model (Tobit)

\begin{tabular}{lcccc}
\hline & Coefficient & Std. Error & z-Statistic & Prob. \\
\hline C & 1.728914 & 0.421030 & 4.106389 & 0.0000 \\
MNGMTRATE $^{a}$ & 0.094284 & 0.031259 & 3.016206 & 0.0026 \\
TECHFACTOR $^{b}$ & -0.266903 & 0.105296 & -2.534776 & 0.0113 \\
INFRAFACTOR $^{c}$ & 0.083449 & 0.070586 & 1.182231 & 0.2371 \\
CEORATE & -0.106984 & 0.050400 & -2.122691 & 0.0338 \\
GROWDIFF & 0.005953 & 0.001971 & 3.020018 & 0.0025 \\
ROADIFF & 0.005682 & 0.002051 & 2.770016 & 0.0056 \\
\hline Left censored obs & 2 & \multicolumn{4}{c}{ Right censored obs } & 0 \\
Uncensored obs & 8 & \multicolumn{2}{c}{ Total obs } & 10 \\
\hline \hline
\end{tabular}

${ }^{\mathrm{a}} \mathrm{H}_{1},{ }^{\mathrm{b}} \mathrm{H}_{2},{ }^{\mathrm{c}} \mathrm{H}_{3}$ at the significant level (a=5\%)

Table 4 summarizes the results of the Tobit analysis. Three variables in the model are significant predictors of the duration of competitive advantage at $\rho<\alpha=5 \%$. Management rating, ROA differential, and growth differential are positively related to the duration. The ability of management to conceive, develop and exploit IT application has a contribution to the duration. This is in line with the study of Dehning and Stratopoulos (2003). Consistent with the prior findings (Dehning and Stratopoulos, 2003; Bharadwaj, 2000; Castanias and Helfat, 1991; Katz, 1974; Mata et al., 1995), these results suggest that the companies with superior managerial IT skills are more likely to sustain an IT-enabled competitive advantage. The other findings are CEO rating, technical IT skills and infrastructure factor, which are not significantly related to the duration. The negative signs on technical IT skills and CEO rating are insignificantly related to the duration of competitive advantage, $\rho>a=5 \%$. The findings of 
technical IT skills and IT infrastructure are insignificantly related to the duration is in line with the argument of Mata et.al (1995). They argued that the technical IT skills factor was not significantly related to the duration. The IT infrastructure was also not related to the duration.

The important findings in this research are the ROA differential and growth differential. In the journal of Dehning and Stratopoulos (2003), these two variables were not significantly related to the duration. Meanwhile, in this research, ROA differential and growth differential have contribution to the duration. At the prior research of Dehning and stratopoulos (2000), they suggest that companies that have implemented IT-enabled strategy have an accounting performance advantage over their direct competitors. This statement supports the findings.

The results show the fact that most of companies in Indonesia use IT as basic usage such as administrative activities. In the survey for The Best e-Corporation conducted by Swa magazine shows that most of the nominees have realized the function of IT but it is only used for minimum physical sector. Moreover, few companies have implemented IT to increase their business value. The significant results of ROA differential and growth differential are related to the duration of competitive advantage is the impact of the IT development in Indonesian economic environment.

\section{Research Implication}

The results of regression show that there are three factors related to the duration. As predicted before, managerial IT skills have contribution to the duration. It means the probability of the duration competitive advantage will be longer when the management ability to conceive, develop and exploit IT is getting better. Two of the control variables in the model, ROA differential and growth differential, are also related to the duration of competitive advantage. According to Bharadwaj (2000), recent research in the area of information technology (IT) and competitive advantage has shown that high IT-capable firms outperform their direct competitors on a number of performances measures. Weill and Broadbent (1990) also defines strategic IT as an "investment made to gain a competitive and gain market share via sales growth. Clemons (1986) states that strategic systems have "two sources of benefits to the firm: increased profit margins and increased market share". According to Turban, Mclean and Wetherbe (2002), ROA shows how the company performs its business activities and profit growth rate in five-year shows how the company establishes business performance

The implication of this research is that ROA differential and the profit growth have a role in determining the period of competitive advantage. The company that is more focus in controlling their ROA and profit growth will have higher chance to sustain their competitive advantage over their rivals. In other words, the companies with better financial performance especially its profitability can sustain their competitive advantage for long term. 
In the research of Dehning and Stratopoulos (2003), CEO rate is negatively related to the duration. Meanwhile in this research, CEO rate is related insignificantly to the duration. It is because the fact that most of CEO in Indonesia's companies still have lack commitment on IT. They have less contribution to integrate the IT in their organizational culture. There is an article "25 Best e-corporation" issued by Swa magazine 24th edition, tells that CEO and top-level management have an important role to make the IT implementation succeeds.

\section{CONCLUSIONS, LIMITATIONS, AND RECOMMENDATIONS}

\section{Conclusions}

This research analyzes the role of several factors that has contributed to the sustainability of IT-enabled competitive advantage. The empirical analysis supports the argument that a competitive advantage due to an IT-enabled strategy is more likely sustainable if it is built on the managerial expertise of the organization. Consistent to the previous research, Dehning and Stratopoulos (2003) find that managerial IT skills are a source of sustainability. On the contrary, there are no significant results for technical IT skills and IT infrastructure are related to the duration. Meanwhile, ROA differential and profit growth differential as the impact of Indonesian economic condition, are related to the duration of competitive advantage. There are only few companies, which have implemented IT as enabler. In addition, this condition has made the financial performance as an important factor of competitive edge, which means a company's profitability can sustain the competitive advantage.

\section{Limitations}

The limitations of the study are; the ROA differential in 2003 is suggested to use the financial statement audited 2003. It is difficult to find the company's financial statement audited 2003 because many companies have not issued their financial statement in Jakarta Stock Exchange. This research assumes that the financial statements were audited quarterly in September 2003; this research only analyzes the duration of competitive advantage and factors believed can sustain the competitive advantage from the censored regression; these research samples of data are matching through the matching concept. The different industry sector applied in Warta ekonomi is assumed as the same as the ICMD (Indonesian Capital market Directory). Therefore, the industry sector uses ICMD as a source; because of the Variables used in this research are adjusted from the e-company award 2002 criteria conducted by Warta Ekonomi (Warta Ekonomi No.23/THN.XIV/9 Oktober 2002). There are only several Warta Ekonomi criteria used in this research, those are management rate assumed to be measured by innovation rate, technical factor measured from human resources rate, and infrastructural factor calculated from the internet used rate; The validity of the dataset is based on the ability of Warta Ekonomi to identify companies that successfully an IT enabled-strategy. Another issue is that this re- 
search measurement is a longitudinal comparisons, at least the company as the sample has implemented IT for 5 years and still in the active file. The implementation of IT in Indonesia is still young, there are only few companies have implemented IT more than five years, most of Indonesian companies are the beginner and less experience in IT implementation. This condition can affect the research results

\section{Recommendations}

By seeing the limitations in this research, there are several suggestions that expectedly can give contribution for the future researcher. The future researcher can add other possibility variables, which are considered as the factors of competitive advantage. This research will have contribution for the future researcher on the information technology and competitive advantage. This research gives contribution to the Indonesian companies, which are going to sustain their competitive advantages with an IT strategy, to be more concern to the factors that are believed can lead to a sustainable competitive advantage.

\section{APPENDICES}

\section{Appendix A. Censored regression models}

The general formulation of the censored regression model is $y^{*}=\beta^{\prime} x i+\varepsilon i$,

Where yi ${ }^{\star}$ refers to the number of consecutive years a company sustains its competitive advantage. The latent variable, yi is observed for values greater than zero (when the company enjoys competitive advantage, and censored for values less or equal to zero (when the company does not enjoy competitive advantage). On the other hand $x$ 's, the vector of explanatory and control variables, are observed for all cases, and $\varepsilon$ i iid $\sim \mathrm{N}\left(0, \sigma^{2}\right)$.

To analyze the distribution, we define a new random variable yi transformed from the original one yi ${ }^{\star}$, by Eq. (A2).

$\mathrm{yi}=\left\{\mathrm{yi}^{\star}\right.$ if $\mathrm{yi}^{*}>0,0$ if $\left.\mathrm{yi}^{\star} \leq 0\right\}$

or yi $\left\{\mathrm{yi}^{\star}=\mathrm{xi} \beta+\varepsilon \mathrm{i}\right.$ if $\mathrm{yi}^{*}>0,0$ if $\left.\mathrm{yi}^{\star} \leq 0\right\}$

The distribution that applies if $\mathrm{y}^{*^{*}} \mathrm{~N}\left[\mathrm{xi} \beta, \sigma^{2}\right]$ is

$\operatorname{Prob}(y=0)=\operatorname{Prob}\left(y^{*} \leq 0\right)=\varphi(-x i \beta / \sigma)=1-\varphi(x i \beta / \sigma)$,

and if $y^{*}>0$, y has the density of $y^{*} . \varphi()$ is the standard normal cumulative density function.

The estimation is done using the Maximum Likelihood method. The loglikelihood for the censored regression model is

$\ln L=\Sigma_{y>0}-1 / 2\left[\ln (2 \pi)+\ln \sigma^{2}+\left(y i-\beta^{\prime} x i\right)^{2} / \sigma^{2}\right]+\Sigma_{y i=0} \ln [1-\varphi(x i \beta / \sigma)]$

The two parts correspond to the classical regression for the non-limit observations (companies with competitive advantage) and the relevant probabilities for the limit observations, respectively (companies without a competitive advantage). 
$L=\Pi_{y i>0} 1 / \sqrt{2} 2 \pi \sigma^{2} \cdot e^{-1 / 2\left[y i-\beta^{\prime} x i l \sigma\right] 2} \cdot \Pi_{y i=0}[1-\varphi(x i \beta / \sigma)]$

The likelihood consists of the product of expressions for the probability of obtaining each observation. The probability for a limit observation therefore must be the probability of getting an observation for a company without competitive advantage, which would be the integral below zero of the appropriate density function.

For an observation randomly drawn from the population, which may or may not be censored,

$E[y i \mid x i]=\varphi\left(\beta^{\prime} x i / \sigma\right)\left(\beta^{\prime} x i+\sigma \lambda i\right)$, where $\lambda i=\frac{\varphi\left(\beta^{\prime} x i / \sigma\right)}{\varphi\left(\beta^{\prime} x i / \sigma\right)}$

For yi, given the censoring, the marginal effect is only

$\delta$ E[yi $\mid x i] / \delta x i=\beta(\beta ' x i / \sigma)$

The slope of vector can be further decomposed into

$\delta E[y i \mid x i] / \delta x i=\operatorname{Prob}[y i>0] \delta E[y i \mid x i, y i>0] / \delta x i+\delta \operatorname{Prob}[y i>0] / \delta x i$

The change in xi has two effects. It affects the conditial mean of yi* in the positive part of the distribution and the probability that the distributions will fall in that part of the distribution ( Dehning and Stratopoulos, 2003)

\section{REFERENCES}

Arief, Mochamad. 2002. Metodologi: Menilai E-Company di Indonesia. No. 23 / THN.XIV/ Oktober 9. Warta Ekonomi, 26-32.

Bergevin, Peter M. 2002. Financial Statement Analysis an Integrated Approach. International Edition. New Jersey: Pearson Education, Inc.

Day, George S., Reibstein, David J. and Gunther, Robert E. 1997. Wharton on Dynamic Competitive strategy. Canada: John Wiley \& Sons, Inc.

Dehning, Bruce and Stratopoulos, Theophanis. 2002. DuPont Analysis of an ITenabled competitive advantage. International Journal of Accounting Information Systems 3:165-176.

Dehning, Bruce and Stratopoulos, Theophanis. 2003. Determinants of a sustainable competitive advantage due to an IT-enabled strategy. Journal of Strategic Information Systems 12:7-28.

Gujarati, Damodar. 2003. Basic Econometrics. Fourth Edition. Singapore: McGrawHill, Inc.

Dorimulu, Primus. May 22-June 4, 2002. 100 Emiten Terbaik 2002: Yang Terdepak dan Yang Meraih 'Award'. 55th Edition. Investor. 
Kettinger, William J., Grover, Varun., Guha, Subashish. and Segars, Albert H. March 1994. Strategic Information Systems Revisited: A Study in Sustainability and Performance. MIS Quarterly 18 (1), 31-58.

Mason, Robert D., Lind, Douglas A. and Marchal, William G. 1999. Statistical Techniques in Business and Economics. 10th Edition. McGraw-Hill Companies, Inc.

O'Brien, James A. .2002. Management Information System: Managing IT in the EBusiness Enterprise. Fifth edition. McGraw-Hill Irwin Co.

Palepu, Bernard and Healy. 1996. Business Analysis and valuation Using Financial Statement. United States: South-Western publishing Co.

Pambudi, Teguh S. 2004. Sajian Utama: Agar TI Sanggup Mencetak Value. SWA 24/XX/ November 25 - December 8. SWA Sembada, 52-57.

Perkins, William C., et al. 1999. Managing IT what managers need to know. 3rd Edition. Prentice Hall, Inc.

Turban, Mclean, and Wetherbe. 2002. Information Technology for Management Transforming Business in The Digital Economy. 3rd Edition. United States: John Wiley \& Sons, Inc.

White, Gerald I., Sondhi, Ashwinpaul C. and Fried, Dov. 1994. The Analysis and Use of Financial Statements. United States: John Wiley \& Sons, Inc.

http://www.elsevier.com/locate/jsis

http://www.jsx.co.id 